\title{
A Special Focus on ANZACATA
}

The Australian, New Zealand and Asian Creative Arts Therapies Association (ANZACATA) is an international professional organization that uniquely embodies the mission of our journal and its commitment to East-West dialogue and cooperation. The editors are grateful to the contributing authors for their involvement in this issue and we strongly encourage future submissions exploring Eastern and Western perspectives from the ANZACATA community. We admire the Association's journal, ANZJAT https://www.anzacata.org/Journal, as a leading international publication and hope that the East-West focus of this journal can complement it through its focus on China and its neighbors. ANZACATA members are doing so much on an ongoing practical basis to realize the aspirations of Creative Arts in Education and Therapy: Eastern and Western Perspectives and we look forward to ongoing cooperation.

The CAET Executive Editorial Committee

澳新亚创造性艺术治疗协会 (ANZACATA ) 是一个国际性的专业组织，其独树 一帜的宗旨也体现了CAET期刊的使命和推动东西方对话与合作的承诺。我们的 编辑很感谢所有付出努力的作者们参与这一期的出版，也强烈鼓励未来更多来 自ANZACATA社群探索东西方视角的投稿。我们很钦佩协会创办的重要的国际 性期刊ANZJAT http:/www.anzacata.org/Journal，希望CAET期刊的东西方焦点对中 国和其邻国的关注可以对ANZJAT有所补充。澳新亚创造性艺术治疗协会的成员 们为实现CAET期刊 “创造性艺术教育及治疗一东西方视角” 秉持的愿景不断地 进行大量以实践为基础的工作，我们也期待持续与协会合作。

CAET执行编委会 